\title{
Collection and morphological characterization of sweet potato landraces in north of Rio de Janeiro state
}

\author{
Monique M Moulin'; Rosana Rodrigues ${ }^{1}$; Leandro SA Gonçalves ${ }^{1}$; Cláudia P Sudré1; Marilene H dos \\ Santos $^{1}$; José Roberto P da Silva ${ }^{2}$ \\ ${ }^{1}$ UENF-LMGV, Av. Alberto Lamego 2000, Pq. Califórnia, 28013-602 Campos dos Goytacazes-RJ moniquemoulin@gmail.com; \\ ${ }^{2}$ EMATER, R. Visconde de Inhaúma 102, Pq. Tamandaré, 28030-160 Campos dos Goytacazes-RJ
}

\begin{abstract}
The traditional farmers play an important role in plant genetic resources conservation. Collecting the germplasm maintained by these farmers is a very important action to avoid genetic variability losses. The goals of this work were to collect sweet potato from farms in the north of Rio de Janeiro state; to gather information regarding to the farmers profile, and to characterize the sweet potato landraces collected using morphological descriptors. Fifty three farms were visited in six collection expedition and 46 accessions were collected. During the visits the farmers were interviewed using a query with ten items. Six root traits and eight descriptors for vegetative parts were used for morphological characterization. The data were analyzed based on Cole-Rodgers distance and clustering was done with UPGMA method. Familiar agriculture with subsistence objective was observed and sweet potato was cultivated by $72 \%$ of the farmers at least for more than a decade, supporting the observation that this vegetable is traditionally cultivated in small areas in the specific region. The morphological characterization was efficient to detect genetic variability among accessions, revealing that traditional farmers from Campos dos Goytacazes and São João da Barra are responsible for sweet potato genotypes conservation with expressive genetic diversity in their properties. There was no relationship between genetic distance and collecting areas.
\end{abstract}

Keywords: Ipomoea batatas, genetic resources, traditional agriculture, germplasm characterization, agrobiodiversity.

\section{RESUMO}

Coleta e caracterização morfológica de variedades locais de batata-doce no norte do Rio de Janeiro

Os agricultores tradicionais têm um papel fundamental na conservação dos recursos genéticos vegetais e a coleta de germoplasma mantido por esses produtores é muito importante para evitar a perda da variabilidade genética. Os objetivos deste trabalho foram coletar germoplasma de batata-doce em propriedades rurais situadas no norte do estado do Rio de Janeiro; levantar informações quanto ao perfil dos produtores rurais visitados durante as coletas, e caracterizar morfologicamente as variedades locais de batata-doce coletadas. Em seis viagens de coleta foram visitadas 53 propriedades rurais, e coletados 46 acessos. Em todas as visitas foi possível entrevistar o produtor por meio de questionário contendo dez itens. Para a caracterização, foram usados seis caracteres de raiz e oito da parte aérea. A análise dos dados foi efetuada com o uso da distância de Cole-Rodgers e o agrupamento foi gerado com o método UPGMA. Foi constatado predomínio da agricultura familiar, voltada para subsistência, sendo que $72 \%$ dos agricultores cultivavam a batata-doce há mais de uma década, o que evidencia a tradição de cultivo desta hortaliça em pequenas áreas na região. A caracterização morfológica foi eficiente para detectar a variabilidade genética entre os acessos, demonstrando que os agricultores tradicionais dos municípios de Campos dos Goytacazes e São João da Barra detêm genótipos de batata-doce com expressiva diversidade genética em suas propriedades. Não foi detectada correlação entre a distância genética e os locais de coleta.

Palavras-chave: Ipomoea batatas, recursos genéticos, agricultura tradicional, caracterização de germoplasma, agrobiodiversidade.

(Recebido para publicação em 15 de fevereiro de 2011; aceito em 20 de março de 2012) (Received on February 15, 2011; accepted on March 20, 2012)

$\mathrm{T}$ he sweet potato (Ipomoea batatas) belongs to the Convolvulaceae family and is cropped throughout Brazil. It is a rustic crop which produces well in poor nutrients soils conditions, and it is often related to low incidence of pests or limiting diseases, high drought tolerance and low production cost (Roesler et al., 2008). Because of this rusticity, sweet potato is very frequently associated with small farmers which are responsible for maintenance of many genetic diversity of the crop in on farm conservation.

One of the main characteristics of the sweet potato is its high phenotypic and genotypic variability (Vilas Boas et al., 1999; Veasey et al., 2007) that confers adaptability to different edaphoclimatic conditions. The sweet potato has been cropped empirically by most farmers (Zero \& Lima, 2005) and much of what is known about the sweet potato comes from popular knowledge. The occurrence of the same cultivar with different names and vice versa is quite common (Daros et al., 2002). This way, collecting sweet potato germplasm in rural properties would implicate in a situation which two different accessions in a gene bank could correspond to the same genotype. Duplicate genotypes in gene banks can be identified by, for example, morphological characterization of the germplasm which is normally the most feasible way to quantify its genetic diversity and has been frequently used (Rabbani et al., 1998; Ritschel et al., 2002). Morphological characterization activities make available information on the conserved germplasm, placing it in the most effective form for use, and it is 
important to emphasize that the value of the germplasm increases as it becomes known and documented (Painting et al., 1995; Sudré et al., 2010).

Rural communities can contribute to the use and conservation of germplasm adapted to the agricultural ecosystems of the agricultural communities (Almekinders \& Elings, 2001). Family agriculture is an economic segment that generates employment and income for many Brazilians and small farmers depend on this income and benefits to ensure the survival of their children and other dependents (Brasil, 2009). The practice of cropping local varieties is intrinsically linked to the cultural context related to the lifestyle of the families and their associated traditional knowledge (Albagli \& Maciel, 2004).

Despite of the importance of maintaining the crops genetic variability that exists on small farms, the modernizations of agriculture and rural exodus have caused loss of genetic diversity in crops, including the sweet potato. Thus it is essential to collect and to conserve germplasm and keep it in organized collections for later characterization, evaluation and documentation (Cabral et al., 2010). This way it will be possible to estimate the real variability maintained to make the conserved germplasm available for effective use by researchers in several areas such as breeders and botanists or even the farmers themselves.

The objectives of the present study were to collect local sweet potato varieties on farms in the northern region of Rio de Janeiro state; to gather information regarding the profile of the farmers who traditionally cultivate and maintain sweet potato germplasm and to characterize the accessions collected based on morphological descriptors.

\section{MATERIAL AND METHODS}

Six collection expeditions were made from March to April 2009 and roots from 46 sweet potato accessions were collected on small rural properties located in the north of Rio de Janeiro state including the municipalities of Campos dos Goytacazes and São João da Barra (Table 1). A GPS (global positioning system) equipment was used to geo-reference the collection points. The collection locations were defined with support from the Empresa de Assistência Técnica e Extensão Rural do Rio de Janeiro (Emater-Rio). At the time of collection, each farmer answered a questionnaire previously designed to understand his profile, considering the following items: farmers' name; collection location; local name for the sweet potato; procedence of the cropped genotypes; end destination for the product; pest and disease incidence in the crop; chemical product application; annual yield and time the farmer had exercised this activity. Considering that the collection was made on commercial fields of small farmers, and meaning to cause no financial loss for the farmers and because the crop is propagated by vegetative propagation, only three roots from each accession, representative of the field, were collected in each location sampled.

The roots collected from the farmers were taken to the Laboratorio de Melhoramento Genetico Vegetal (LMGV) at UENF on the same day and characterized shortly after collection, considering six root morphological descriptors (shape, surface defects, skin color, skin color intensity, flesh color and secondary flesh color) proposed by Huamán (1991). After characterization, the roots were kept under ambient conditions in the Plant Genetic Resources Sector of the LMGV at $25^{\circ} \mathrm{C}$ and approximately $75 \%$ humidity for 30 days until six or eight sprouts had formed, that were then transferred to $5 \mathrm{~L}$ pots to multiply the accessions in a greenhouse. At this phase, the accessions were characterized by eight sweet potato-specific morphological descriptors (Huamán, 1991) (Table 2).

Ninety days after transplant the characteristics of the vegetative part were assessed, by sampling eight leaves and roots from each accession in the greenhouse. The data obtained for both the roots and canopy were analyzed using the Genes program (Cruz, 2006) to obtain the similarity matrix and by the R program (http://www.r-project.org) to obtain the dendrogram. The Cole-
Rodgers et al. (1997) distance was used to calculate the genetic distance matrix and the dendrogram was obtained by the Unweighted Paired Group Method using Arithmetic averages (UPGMA).

\section{RESULTS AND DISCUSSION}

Fifty-three farms were visited in the six collection trips, including 31 locations in the municipalities of Campos dos Goytacazes and São João da Barra. Sweet potato germplasm was collected in 46 locations visited, because on some farms the root was not yet available or the farmer had abandoned the crop. A predominance of traditional family agriculture was observed, and about $72 \%$ of the rural producers interviewed said they had planted sweet potato for more than a decade. The main advantage emphasized by the rural producers was the regularity of the crop production, and most reported disadvantages with low prices and difficulty in marketing production. Products characteristic of traditional agriculture include pineapple, yam, cassava, corn, sugarcane, sweet potato and other crops. However, few are produced regularly and only sweet potato is produced with greater frequency (Targino \& Couto, 2007).

It was also observed that sweet potato was planted for subsistence on the properties visited. Sweet potato has been cropped empirically over time by rural families, usually with other vegetables as an alternative in case there is a fall in price of one of the products cropped. According to Souza et al. (2008), one of the characteristics of family production is polycropping. Although they cultivate a main product for the market, small farmers generally dedicate themselves to other activities, either to commercialize or simply for the family subsistence.

According to the questionnaire, it was further observed that investment in the sweet potato crop is very low and the main argument mentioned against increasing technology for this crop is that the profits are small, a fact resulting from the small production volume. It is important to emphasize that the cost estimated with production reflect 
Table 1. Identification of sweet potato accessions, with their number in the collection, common name, municipality of origin, latitude and longitude of the collection points (identificação dos acessos de batata-doce, com a respectiva numeração na coleção, nome comum, município de procedência, e valores de latitude e longitude dos pontos de coleta). Campos dos Goytacazes, UENF, 2009.

\begin{tabular}{|c|c|c|c|c|c|}
\hline Number & Accession & Common Name & Procedence & Latitude & Longitude \\
\hline 1 & UENF 1917 & Três meses & Campos dos Goytacazes & $21^{\circ} 54^{\prime} 27.3^{\prime \prime}$ & $41^{\circ} 02^{\prime} 30.2^{\prime \prime}$ \\
\hline 2 & UENF 1918 & Comum & Campos dos Goytacazes & $21^{\circ} 57^{\prime} 04.9^{\prime \prime}$ & $41^{\circ} 03^{\prime} 46.9^{\prime \prime}$ \\
\hline 3 & UENF 1919 & Comum & Campos dos Goytacazes & $21^{\circ} 57^{\prime} 57.5^{\prime \prime}$ & $41^{\circ} 14^{\prime} 34.8^{\prime \prime}$ \\
\hline 4 & UENF 1920 & Comum & Campos dos Goytacazes & $21^{\circ} 57^{\prime} 08.5^{\prime \prime}$ & $41^{\circ} 08^{\prime} 19.2^{\prime \prime}$ \\
\hline 5 & UENF 1921 & Rosa & Campos dos Goytacazes & $21^{\circ} 37^{\prime} 06.1^{\prime \prime}$ & $41^{\circ} 13^{\prime} 20.1^{\prime \prime}$ \\
\hline 6 & UENF 1922 & Branca & Campos dos Goytacazes & $21^{\circ} 37^{\prime} 21.4^{\prime \prime}$ & $41^{\circ} 13^{\prime} 12.2^{\prime \prime}$ \\
\hline 7 & UENF 1923 & Marron & Campos dos Goytacazes & $21^{\circ} 37^{\prime} 21.4^{\prime \prime}$ & $41^{\circ} 13^{\prime} 12.2^{\prime \prime}$ \\
\hline 8 & UENF 1924 & Comum & Campos dos Goytacazes & $21^{\circ} 37^{\prime} 21.4^{\prime \prime}$ & $41^{\circ} 13^{\prime} 12.2^{\prime \prime}$ \\
\hline 9 & UENF 1925 & Banha de Galinha & Campos dos Goytacazes & $21^{\circ} 39^{\prime} 01.7^{\prime \prime}$ & $41^{\circ} 11^{\prime} 20.2^{\prime \prime}$ \\
\hline 10 & UENF 1926 & Comum & Campos dos Goytacazes & $21^{\circ} 39^{\prime} 01.7^{\prime \prime}$ & $41^{\circ} 11^{\prime} 20.2^{\prime \prime}$ \\
\hline 11 & UENF 1930 & Rosada & São João da Barra & $21^{\circ} 46^{\prime} 30.8^{\prime \prime}$ & $41^{\circ} 18^{\prime} 35.2^{\prime \prime}$ \\
\hline 12 & UENF 1931 & Comum & Campos dos Goytacazes & $21^{\circ} 46^{\prime} 30.8^{\prime \prime}$ & $41^{\circ} 18^{\prime} 35.2^{\prime \prime}$ \\
\hline 13 & UENF 1932 & Comum & São João da Barra & $21^{\circ} 45^{\prime} 41.2^{\prime \prime}$ & $41^{\circ} 17^{\prime} 26.7^{\prime \prime}$ \\
\hline 14 & UENF 1933 & Comum & Campos dos Goytacazes & $21^{\circ} 45^{\prime} 38.2^{\prime \prime}$ & $41^{\circ} 18^{\prime} 15.7^{\prime \prime}$ \\
\hline 15 & UENF 1935 & Comum & São João da Barra & $21^{\circ} 45^{\prime} 29.3 ”$ & $41^{\circ} 19^{\prime} 33.6^{\prime \prime}$ \\
\hline 16 & UENF 1936 & Comum & Campos dos Goytacazes & $21^{\circ} 46^{\prime} 07.3^{\prime \prime}$ & $41^{\circ} 19^{\prime} 44.1^{\prime \prime}$ \\
\hline 17 & UENF 1937 & Comum & São João da Barra & $21^{\circ} 46^{\prime} 31.6^{\prime \prime}$ & $41^{\circ} 19^{\prime} 11.1^{\prime \prime}$ \\
\hline 18 & UENF 1941 & Comum & São João da Barra & $21^{\circ} 44^{\prime} 56.7^{\prime \prime}$ & $41^{\circ} 19^{\prime} 34.3^{\prime \prime}$ \\
\hline 19 & UENF 1946 & Comum & São João da Barra & $21^{\circ} 45^{\prime} 43.2^{\prime \prime}$ & $41^{\circ} 19^{\prime} 34.3^{\prime \prime}$ \\
\hline 20 & UENF 1948 & Comum & São João da Barra & $21^{\circ} 45^{\prime} 29.4^{\prime \prime}$ & $41^{\circ} 20^{\prime} 25.6^{\prime \prime}$ \\
\hline 21 & UENF 1949 & Vermelha & Campos dos Goytacazes & $21^{\circ} 57^{\prime} 05.1^{\prime \prime}$ & $41^{\circ} 03^{\prime} 45.7^{\prime \prime}$ \\
\hline 22 & UENF 1950 & Penquinha & Campos dos Goytacazes & $21^{\circ} 56^{\prime} 13.4^{\prime \prime}$ & $41^{\circ} 00^{\prime} 24.0^{\prime \prime}$ \\
\hline 23 & UENF 1951 & Comum & Campos dos Goytacazes & $21^{\circ} 56^{\prime} 31.1^{\prime \prime}$ & $41^{\circ} 00^{\prime} 13.8^{\prime \prime}$ \\
\hline 24 & UENF 1952 & Vermelha & São João da Barra & $21^{\circ} 56^{\prime} 00.0^{\prime \prime}$ & $40^{\circ} 59^{\prime} 53.4^{\prime \prime}$ \\
\hline 25 & UENF 1953 & Três meses & São João da Barra & $21^{\circ} 56^{\prime} 03.2^{\prime \prime}$ & $40^{\circ} 59^{\prime} 28.0^{\prime \prime}$ \\
\hline 26 & UENF 1954 & Comum & Campos dos Goytacazes & $21^{\circ} 49^{\prime} 24.7^{\prime \prime}$ & $41^{\circ} 17^{\prime} 45.2^{\prime \prime}$ \\
\hline 27 & UENF 1955 & Rosada & Campos dos Goytacazes & $21^{\circ} 54^{\prime} 31.8^{\prime \prime}$ & $41^{\circ} 16^{\prime} 32.4^{\prime \prime}$ \\
\hline 28 & UENF 1956 & Branca & Campos dos Goytacazes & $21^{\circ} 57^{\prime} 41.0^{\prime \prime}$ & $41^{\circ} 14^{\prime} 17.7^{\prime \prime}$ \\
\hline 29 & UENF 1957 & Comum & Campos dos Goytacazes & $21^{\circ} 57^{\prime} 58.2^{\prime \prime}$ & $41^{\circ} 14^{\prime} 35.5^{\prime \prime}$ \\
\hline 30 & UENF 1958 & Roxa & Campos dos Goytacazes & $22^{\circ} 05^{\prime} 09.2^{\prime \prime}$ & $41^{\circ} 10^{\prime} 09.7^{\prime \prime}$ \\
\hline 31 & UENF 1959 & Dr. Ney & Campos dos Goytacazes & $22^{\circ} 05^{\prime} 00.7^{\prime \prime}$ & $41^{\circ} 10^{\prime} 07.5^{\prime \prime}$ \\
\hline 32 & UENF 1960 & Rainha & Campos dos Goytacazes & $21^{\circ} 36^{\prime} 33.6^{\prime \prime}$ & $41^{\circ} 18^{\prime} 59.2^{\prime \prime}$ \\
\hline 33 & UENF 1961 & Rainha & Campos dos Goytacazes & $21^{\circ} 38^{\prime} 26.4^{\prime \prime}$ & $41^{\circ} 16^{\prime} 55.4^{\prime \prime}$ \\
\hline 34 & UENF 1962 & Comum & Campos dos Goytacazes & $21^{\circ} 38^{\prime} 08.6^{\prime \prime}$ & $41^{\circ} 16^{\prime} 32.3^{\prime \prime}$ \\
\hline 35 & UENF 1963 & Branca & Campos dos Goytacazes & $21^{\circ} 37^{\prime} 06.1^{\prime \prime}$ & $41^{\circ} 13^{\prime} 20.1^{\prime \prime}$ \\
\hline 36 & UENF 1964 & Rosada & Campos dos Goytacazes & $21^{\circ} 37^{\prime} 06.1^{\prime \prime}$ & $41^{\circ} 13^{\prime} 20.1^{\prime \prime}$ \\
\hline 37 & UENF 1965 & Penquinha & Campos dos Goytacazes & $21^{\circ} 37^{\prime} 07.4^{\prime \prime}$ & $41^{\circ} 13 ’ 23.4^{\prime \prime}$ \\
\hline 38 & UENF 1966 & Roxa & Campos dos Goytacazes & $21^{\circ} 37^{\prime} 09.4^{\prime \prime}$ & $41^{\circ} 13^{\prime} 23.4^{\prime \prime}$ \\
\hline 39 & UENF 1967 & Graúda & Campos dos Goytacazes & $21^{\circ} 36^{\prime} 42.8^{\prime \prime}$ & $41^{\circ} 13^{\prime} 11.4^{\prime \prime}$ \\
\hline 40 & UENF 1968 & Vermelha & Campos dos Goytacazes & $21^{\circ} 37^{\prime} 11.4^{\prime \prime}$ & $41^{\circ} 14^{\prime} 15.7^{\prime \prime}$ \\
\hline 41 & UENF 1969 & Costa & São João da Barra & $21^{\circ} 43^{\prime} 48.1^{\prime \prime}$ & $41^{\circ} 07^{\prime} 48.8^{\prime \prime}$ \\
\hline 42 & UENF 1970 & Penquinha & São João da Barra & $21^{\circ} 54^{\prime} 28.8^{\prime \prime}$ & $41^{\circ} 05^{\prime} 46.6^{\prime \prime}$ \\
\hline 43 & UENF 1971 & Vermelha & São João da Barra & $21^{\circ} 53^{\prime} 53.9^{\prime \prime}$ & $41^{\circ} 05^{\prime} 40.5^{\prime \prime}$ \\
\hline 44 & UENF 1972 & Rosada & São João da Barra & $21^{\circ} 53^{\prime} 53.9^{\prime \prime}$ & $41^{\circ} 05^{\prime} 40.5^{\prime \prime}$ \\
\hline 45 & UENF 1973 & Comum & Campos dos Goytacazes & $21^{\circ} 26^{\prime} 46.2^{\prime \prime}$ & $41^{\circ} 23^{\prime} 59.9^{\prime \prime}$ \\
\hline 46 & UENF 1974 & Graúda & Campos dos Goytacazes & $21^{\circ} 25^{\prime} 17.8^{\prime \prime}$ & $41^{\circ} 23^{\prime} 52.3^{\prime \prime}$ \\
\hline
\end{tabular}


Table 2. Morphological descriptors used to evaluate roots and vegetative parts of sweet potato accessions collected in north of Rio de Janeiro state (descritores morfológicos utilizados para avaliar as raízes e parte vegetativa dos acessos de batata-doce coletados na região norte do estado do Rio de Janeiro). Campos dos Goytacazes, UENF, 2009.

\begin{tabular}{|c|c|}
\hline Descriptor & Phenotypes \\
\hline \multicolumn{2}{|l|}{ Root } \\
\hline Shape & $\begin{array}{l}1=\text { round; } 2=\text { round elliptic; } 3=\text { elliptic } ; 4=\text { ovate; } 5=\text { obovate; } 6=\text { oblong; } 7=\text { long oblong; } 8=\text { long } \\
\text { elliptic; } 9=\text { long irregular or curved }\end{array}$ \\
\hline Surface defects & $\begin{array}{l}0=\text { absent } ; 1=\text { alligator-like skin; } 2=\text { veins; } 3=\text { shallow horizontal constrictions; } 4=\text { deep horizontal } \\
\text { constrictions; } 5=\text { shallow longitudinal grooves; } 6=\text { deep longitudinal grooves; } 7=\text { deep constrictions } \\
\text { and deep grooves }\end{array}$ \\
\hline Skin color & $\begin{array}{l}1=\text { white } ; 2=\text { cream; } 3=\text { yellow; } 4=\text { orange; } 5=\text { brownish orange; } 6=\text { pink; } 7=\text { red; } 8=\text { purple-red; } \\
9=\text { dark purple }\end{array}$ \\
\hline Skin color intensity & $1=$ pale $; 2=$ intermediate; $3=$ dark \\
\hline Flesh color & $\begin{array}{l}1=\text { white } ; 2=\text { cream; } 3=\text { dark cream; } 4=\text { pale yellow; } 5=\text { dark yellow; } 6=\text { pale orange; } 7=\text { intermediate } \\
\text { orange; } 8=\text { dark orange; } 9=\text { strongly pigmented with anthocyanins }\end{array}$ \\
\hline Flesh secondary color & $\begin{array}{l}0=\text { absent } ; 1=\text { white } 2=\text { cream; } 3=\text { yellow; } 4=\text { orange; } 5=\text { pink; } 6=\text { red; } 7=\text { purple red; } 8=\text { purple; } \\
9=\text { dark purple }\end{array}$ \\
\hline \multicolumn{2}{|l|}{ Leaf } \\
\hline General outline & $1=$ rounded; $2=$ reniform; $3=$ cordate $4=$ triangular; $5=$ hastate $6=$ lobed; $7=$ almost divided \\
\hline Lobe type & $1=$ no lateral lobes; $2=$ very slight (teeth); $3=$ slight; $4=$ moderate; $5=$ deep; $6=$ very deep \\
\hline Lobe number & $1=$ one; $2=$ two $; 3=$ three \\
\hline Shape of central lobe & $\begin{array}{l}1=\text { toothed; } 2=\text { triangular; } 3=\text { semi-circular; } 4=\text { semi-elliptic; } 5=\text { elliptic; } 6=\text { lanceolate; } 7= \\
\text { oblanceolate; } 8=\text { linear }\end{array}$ \\
\hline Mature leaf color & $\begin{array}{l}1=\text { yellow-green; } 2=\text { green; } 3=\text { green with purple edge; } 4=\text { greyish-green; } 5=\text { green with purple } \\
\text { veins on upper surface; } 6=\text { slightly purple; } 7=\text { mostly purple; } 8=\text { green upper surface, purple lower } \\
\text { surface; } 9=\text { purple on both surfaces }\end{array}$ \\
\hline Immature leaf color & $\begin{array}{l}1=\text { yellow-green; } 2=\text { green; } 3=\text { green with purple edge; } 4=\text { greyish-green; } 5=\text { green with purple } \\
\text { veins on upper surface; } 6=\text { slightly purple; } 7=\text { mostly purple; } 8=\text { green upper surface, purple lower } \\
\text { surface; } 9=\text { purple on both surfaces }\end{array}$ \\
\hline Leaf size & $3=$ small $(<8 \mathrm{~cm}) ; 5=$ medium $(8-15 \mathrm{~cm}) ; 7=$ large $(16-25 \mathrm{~cm}) ; 9=$ very large $(>25 \mathrm{~cm})$ \\
\hline Petiole pigmentation & $\begin{array}{l}1=\text { green; } 2=\text { Green with purple near stem; } 3=\text { Green with purple near leaf; } 4=\text { Green with purple } \\
\text { at both ends; } 5=\text { Green with purple spots throughout petiole; } 6=\text { Green with purple stripes; } 7= \\
\text { purple with green near leaf; } 8=\text { some petioles purple, some others green; } 9=\text { totally or mostly purple }\end{array}$ \\
\hline
\end{tabular}

the situation of the family farmers in the northern Fluminense region in the state of Rio de Janeiro who generally develop their activities with a very low technological standard and do not use, for example, irrigation that is a very important technique in the region that is characterized by periods of low rainfall (Souza et al., 2008).

It was observed that $88 \%$ of the sweet potato producers commercialize the product using an intermediary. Studies by Guanziroli \& Cardim (2000) on the degree of integration of family farmers with the market concluded that family agriculture has difficulties to integrate with the market and requires an intermediary in most cases.

Fertilizer or chemical products are not frequently applied. It was also observed that the size of the area cultivated with sweet potato ranged from plantations in very small areas (approximately $0.2 \mathrm{ha}$ ), sometimes in the back yard, and reached a maximum of 2 ha.

While carrying out the interviews by questionnaires, many farmers showed their dissatisfaction and uncertainty of continuing to plant sweet potato because of the many difficulties, especially with marketing the produce, climatic instability (some producers have lost all their production because of heavy rains) and the absence of a substitute to run the rural property, because the producers' children have no interest in remaining in the countryside and go to the cities to study and/or obtain jobs with better income. This emphasizes the importance of collecting and maintaining this germplasm by public research institutions to preserve the genetic variability of these typical small producer crops.

Variation was observed in the six traits studied in the morphological variability estimate of the root descriptor, 


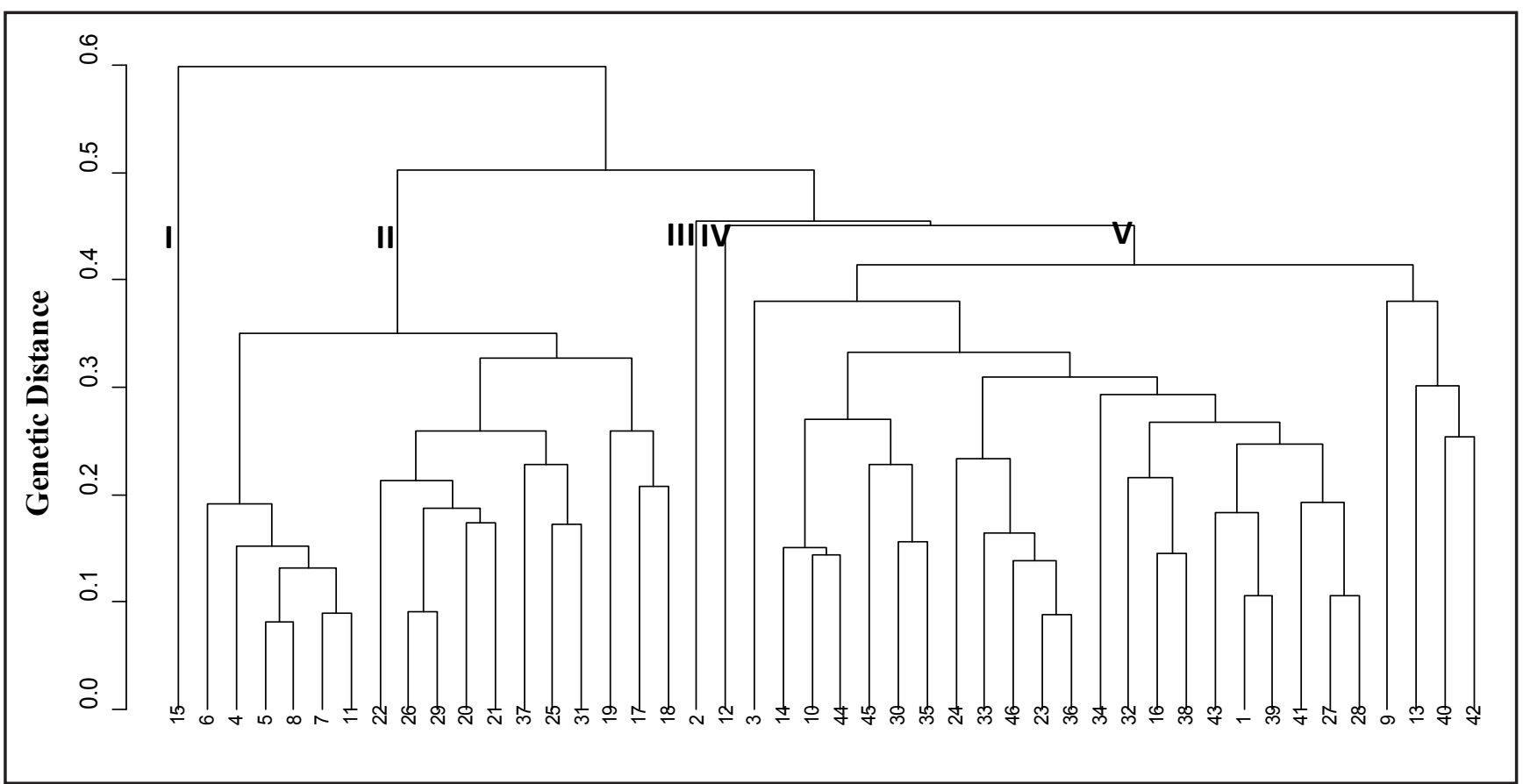

Figure 1. Dendrogram of genetic dissimilarity based on root and vegetative parts descriptors, among 46 sweet potato accessions collected from farms in the north of Rio de Janeiro state (dendrograma de dissimilaridade genética, com base em descritores radiculares e da parte vegetativa, entre 46 acessos de batata-doce coletados em propriedades rurais na região norte do estado do Rio de Janeiro). Campos dos Goytacazes, UENF, 2009.

with different frequencies for each phenotypic class.

Great variability was detected for root shape, with seven classes: round $(8.7 \%)$; elliptic round $(2.2 \%)$; oval (19.6\%); obovate $(4.3 \%)$; long oblong (2.2\%); long elliptic (6.5\%) and long irregular (56.5\%). Ritschel \& Huamán (2002) studied 324 sweet potato accessions and found eight phenotypic classes, with a predominance of those classified as long elliptic (42.5\%) and irregular (21.1\%). However, none of the accessions assessed in the present study was oval in shape.

For the surface defect variable, roots were observed without defects $(67.4 \%)$, alligator skin $(22.2 \%)$, veintype defects (17.4\%), horizontal surface constrictions $(22.2 \%)$ and horizontal superface cracks (8.7\%). Similar results were obtained by Daros et al. (2002) and Cavalcante (2008) who observed all the descriptors in the present study in different proportions. Cavalcante (2008) did not observe predominance of a single class for this descriptor, while Daros et al. (2002) observed predominance of the root classes with vein-type defects and surface constrictions.
The predominant color of the root skin of the accessions characterized was classified as pink (84.8\%), along with the colorings cream $(10.8 \%)$, orangeybrown $(2.2 \%)$ and dark purple (2.2\%). Daros et al. (2002) reported the pink color as predominant $(50 \%)$. However, Chávez et al. (2006) and Veasey et al. (2007) reported predominance of cream coloring while Ritschel \& Huamán classified the skin color as white for $41.2 \%$ of the accessions, and the second greatest frequency was for the pink coloring, represented by $28.6 \%$ of the accessions studied.

The intensity of the skin color was characterized as pale for $19.6 \%$ of the accessions, intermediate for $43.4 \%$ and dark for $37 \%$. Similarly Daros et al. (2002) and Cavalcante (2008) observed all the intensities for root skin color, but the intermediate intensity predominated.

Low variability for the root flesh coloring characteristic was detected, $93.5 \%$ of the accessions had cream colored pulp and $6.5 \%$ had white pulp. Ritschel \& Huamán (2002) observed predominance of the cream color in $75.1 \%$ of the germplasm assessed. Veasey et al. (2007) characterized 73\% of the genotypes with cream-colored flesh. Chávez et al. (2006) observed a great diversity of colors for flesh, but the cream-colored predominated in agreement with the present study and the other authors quoted.

The secondary flesh coloring characteristic of the pulp was absent in $76.1 \%$ and yellow for $23.9 \%$ of the accessions. Chávez et al. (2006) classified $48.6 \%$ of the accessions without secondary pulp. Ritschel \& Huamán (2002) described $50.2 \%$ of the accessions with no secondary coloring and $46.2 \%$ with yellow secondary pulp coloring similar to the data obtained in the present study.

Generally the skin color and root shape characteristics showed the greatest variability, and can be considered an important descriptor in accession clustering, contributing with significant differentiation to the groups. These variables were also mainly responsible for the genetic divergence in the results obtained by Oliveira et al. (2000) and Cavalcante et al. (2009). On the other hand, Veasey et al. (2007) described the secondary pulp coloring diversity, shape and the root surface defects as factors 
that most contributed to diversity. In the present study the characteristics that contributed least to divergence were pulp coloring and secondary root pulp coloring, $93.5 \%$ of the accessions had cream-colored pulp and $76.1 \%$ did not have a secondary pulp color.

High phenotypic variability was observed for the root descriptors. Similar results were reported by Daros et al. (2002) and Chávez et al. (2006) when they assessed 14 and 52 accessions, respectively, based on morphological descriptors for the roots. It is also important that roots collected in the same location or in very close locations had high phenotypic variability, evidence of the cropping of different traditional sweet potato varieties by the rural producers in the northern region of the state of Rio de Janeiro.

Variation was observed for the eight qualitative traits of the canopy of the 46 sweet potato accessions studied, represented by a high number of phenotypic classes, with a significant percentage of individuals in each class.

The following leaf shapes were observed: lobed (50\%), triangular $(37.8 \%)$, cordate $(7.3 \%)$, lanceolate $(3.7 \%)$ and round $(1.2 \%)$. Cavalcante (2008) observed the same shapes in sweet potato accessions as in the present study. The authors observed a greater frequency of the lobed shape $(45.5 \%)$, followed by the triangular $(27.3 \%)$, lanceolate (18.2\%) and cordate (9.1\%) shapes. Daros et al. (2002) analyzed 14 sweet potato accessions and also observed that the lobed shape was predominant, corresponding to $93.0 \%$ of the accessions. However, Ritschel \& Huamán (2002) in the assessment of sweet potato germplasm at Embrapa Hortaliças observed predominance of the cordate shape (49.7\%).

The lobe type characteristic varied greatly among the accessions and five of the six forms of variations were found: no lobe (32.9\%), very superficial lobe $(12.2 \%)$, superficial $(4.9 \%)$, moderate (36.6\%), and deep 13.4\%). However Veasey et al (2007) observed a predominance of very superficial lobe $(40 \%)$ and a much lower frequency of moderate lobe than in the present study, of around $15.0 \%$.
Three categories were observed for the number of lobes: only one lobe $(41.5 \%)$, three lobes $(19.5 \%)$ and five lobes (39\%). Ritschel \& Huamán (2002) reported similar results, classifying $38.2 \%$ of the accessions with only one lobe and $36.4 \%$ with five lobes and these were the two highest frequencies, similar to the present study.

The central aspect of the leaf lobe was characterized as serrated (14.6\%), triangular $(36.6 \%)$, semi-elliptic (41.5\%), elliptic (6.1\%) and lanceolate $(1.2 \%)$ showing great variability for this characteristic. Daros et al. (2002) and Chávez et al. (2006) also found great variation for this trait. However, divergent results were obtained by Cavalcante (2008), who characterized the genotypes in only two categories: $63.7 \%$ as semi-elliptic and $36.3 \%$ as triangular.

Two classes were observed for leaf size: small (34.1\%) and medium (65.9\%) Ritschel \& Huamán (2002) classified the leaves of $80.2 \%$ of the accessions as medium-size while Daros et al. (2002) characterized 100\% of the accessions as having medium-size leaves.

Most of the accessions showed a predominantly green mature leaf coloring (96.4\%), and there were also some accessions with a purple under surface $(3.6 \%)$. For the immature leaf coloring, green leaves were also predominant $(65.8 \%)$ and the rest were represented by green leaves with purple edges and purple nervures on the lower surface (3.7\%). Augustin et al. (2000) obtained $90 \%$ frequency for mature leaf green coloring. Veasey et al. (2007) similarly classified for mature leaf coloring $60 \%$ of the genotypes with green coloring and 40\% with purple nervures on the lower surface. For immature leaf coloring, 50\% of the leaves were classified as green with purple edges $20 \%$, as green leaves, other colorings were also obtained but at lower frequencies.

The petiole coloring showed great variability of types: green (31.7\%), green with scattered purple spots $(1.2 \%)$, green with purple spots close to the leaf $(46.3 \%)$ green with purple spots on both tips $(9.8 \%)$ some purple and other green petiole coloring (6.1\%) and completely or mostly purple (4.9\%). Daros et al. (2002) and Veasey et al. (2007) also reported great petiole coloring variability and detected greater heterogeneity of this characteristic.

The data were grouped by the UPGMA method and by the matrix generated by the Cole-Rodgers distance (Figure 1). The co-phenotypic correlation among the data of the distance matrix and clustering was 0.83 . Sokal \& Rohlf (1995) considered that values over 0.80 indicated good representativeness of the real distances among the genotypes by means of the graphic representation of the dendrogram.

Considering the abrupt change point on the dendrogram, the formation of five groups was observed, and group II and V consisted of most of the accessions, 17 and 26 accessions respectively (Figure 1). The other groups consisted of only one accession each. No definition was observed of the groups according to the collection location. The lack of correlation among the geographic and morphological distances may have been related to the intensive exchange of material for sweet potato planting among the farmers and the length of time that each family crops the same variety. Naskar (1996) and Veasey et al. (2007) also reported an absence in structuring among the morphological diversity and the collection locations and, according to these authors, the fact may be explained by the exchange system among neighboring farmers.

In spite of the innumerable bottlenecks and difficulties reported by the producers, the results allow the conclusion that there is still a tradition of cropping sweet potato among the small producers and that there is great variability among the genotypes planted in the northern region of Rio de Janeiro state. However, there is a great risk of losing this genetic resource, due to the tendency to abandon this activity on the part of the producers, among other factors, and it is up to public organs linked to agricultural teaching and research to take measures to collect and conserve this germplasm for future generations. 


\section{REFERENCES}

ALBAGLI S; MACIEL ML. 2004. Informação e conhecimento na inovação e no desenvolvimento local. Ciência da Informação 33: 9-16.

AUGUSTIN E; GARCIA A; ROCHA BHG. 2000. Caracterização de variedades de batata doce (Ipomoea batatas) através de descritores morfológicos e isoenzimáticos. Ciência Rural 30: 49-53.

ALMEKINDERS CJM; ELINGS, A. 2001. Collaboration of farmers and breeders: participatory crop improvement in perspective. Euphytica 122: 425-438.

BRASIL ERF. 2009. Produção rural familiar em Jataí: permanência e resistência no contexto da modernização agrícola. Uberlândia: UFU. 54p (Tese mestrado).

CABRAL PDS; SOARES TCB; GONÇALVES LSA; AMARAL JÚNIOR AT; LIMA ABP; RODRIGUES R; MATTA FP. 2010. Quantification of the diversity among common bean accessions using Ward-MLM strategy. Pesquisa Agropecuária Brasileira 45: 11241132.

CAVALCANTE M. 2008. Caracterização morfológica, desempenho produtivo e divergência genética de genótipos de batatadoce. Maceió: UFAL. 61p (Tese mestrado).

CAVALCANTE M; FERREIRA PV; PAIXÃO SL; COSTA JG; PEREIRA RG; MADALENA JAS. 2009. Potenciais produtivo e genético de clones de batata-doce. Acta Scientiarum Agronomy 31: 421-426.

CHÁVEZ R; SÁNCHEZ T; IGLESIAS CC. 2006. Caracterización morfológica y molecular de genótipos mejorados de camote (Ipomoea batatas) para ecosistemas Árido-SalinoBórico. Ciência e Desarrollo 8: 84-115.

COLE-RODGERS P; SMITH DW; BOSLAND PW. 1997. A novel statistical approach to analyse genetic resource evaluations using
Capsicum as an example. Crop Science 37: 1000.

DAROS M; AMARAL JR AT; PEREIRA TNS; LEAL NR; FREITAS SP; SEDIYAMA T. 2002. Caracterização morfológica de acessos de batata-doce. Horticultura Brasileira 20: 43-47.

HUAMÁN Z. 1991. Descriptors for sweet potato. Rome: International Board for Genetic Resources/Centro Internacional de la Papa/ Asian Vegetable Research and Development Center. $133 p$.

GUANZIROLI C; CARDIM SE. 2000. Novo retrato da agricultura familiar: o Brasil redescoberto. Brasília: Projeto de Cooperação Técnica FAO/INCRA. 74 p. Disponível em: http://www.incra.gov.br/fao/pub3.html. Acessado em 03 de outubro de 2009.

NASKAR SK. 1996. Genetic divergence for yield contributing traits in sweet potato (Ipomoea batatas). In: KURUP GT; PALANISWAMI MS; POTTY VP; PADMAJA G; LABEERATHUMMA S; PILLAI SV. (ed). Tropical tuber crops: problems, prospects and future strategies. New Hampshire: Science Publishers. p.133-136.

OLIVEIRA ACB; SEDIYAMA MAN; SEDIYAMA T; CRUZ CD. 2000. Avaliação da divergência genética em batata-doce por procedimentos multivariados. Acta Scientiarum 22: 895-900.

PAINTING KA; PERRY MC; DENNING RA; AYAD WG. 1995. Guidebook for genetic resources documentation. Rome: IPGRI, $317 \mathrm{p}$.

RABBANI MA; IWABUCHI A; MURAKAMI Y; SUZUKI T; TAKAYANASHI K. 1998. Variation and the relationship among mustard (Brassica juncea) germplasm from Pakistan. Euphytica 101: 357-366.

RITSCHEL OS; HUÁMAN Z. 2002. Variabilidade morfológica da coleção de germoplasma de batata-doce da Embrapa-Centro Nacional de Pesquisas de Hortaliças. Pesquisa Agropecuária Brasileira. 37: 485-492.

ROESLER PVS; GOMES SD; MORO E; KUMMER ACB; CEREDA MP. 2008 Produção e qualidade de raiz tuberosa de cultivares de batata batata-doce no oeste do Paraná. Acta Scientia Agronômica 30: 117-122.

SOKAL RR; ROHLF FJ. 1995. Biometry: the principles and practice of statistics in biological research. New York: WH Freeman and Company. 120p.

SOUZA PM; FERREIRA VR; PONCIANO NJ; BRITO MN. 2008. Otimização econômica, sob condições de risco, para agricultores familiares das regiões Norte e Noroeste do Estado do Rio de Janeiro. Pesquisa Operacional 28: 123-139.

SUDRÉ CP; GONÇALVES LSA; RODRIGUES R; AMARAL JÚNIOR AT; RIVA-SOUZA EM; BENTO CS. 2010. Genetic variability in domesticated Capsicum spp. as assessed by morphological and agronomic data in mixed statistical analysis. Genetics and Molecular Research 9: 283-294.

TARGINO I; COUTO AI. 2007. Política de créditos e endividamento de trabalhadores assentados: o caso da Zona da Mata Paraibana. Emancipação 7: 135-164.

VEASEY EA; SILVA JRQ; ROSA MS; BORGES AB; PERONI, NEA. 2007. Phenology and morphological diversity of sweet potato (Ipomoea batatas) landraces of the Vale do Ribeira. Scientia Agricola 64:416-427.

VILAS BOAS BM; OKUMURA HH; MALUF WR. 1999. Cultura da batata-doce. Boletim técnico de hortaliças. Lavras, n. 42, p.1-3. Disponível em: http://www2.ufla.br/ wrmaluf/ bth042/bth042.html. Acessado em 03 de agosto de 2008.

ZERO VM; LIMA SL. 2005. Manejo e produtividade da batata-doce (Ipomoea batatas) no Município de Presidente PrudenteSP. Energia na Agricultura 20: 94-117. 